\title{
Transformasi Misi Kristen Pada Isu Dominasi Gender Masyarakat Jawa di Era Masyarakat 5.0
}

\author{
Seri Damarwanti ${ }^{1}$, Sapto Sunariyanti ${ }^{2}$, Suwarni $^{3}$, Lusia Pujiningtyas ${ }^{4}$, Anthoneta Ratu $\mathrm{Pa}^{5}$ \\ Sekolah Tinggi Teologi Nazarene Indonesia \\ Korepondensi: antikmm@yahoo.co.id ${ }^{1}$, sunariyanti@sttni.ac.id ${ }^{2}$,warni20@sttni.ac.id ${ }^{3}$, \\ watitarutung@sttni.ac.id ${ }^{4}$,netaratupa@sttni.ac.id ${ }^{5}$
}

\begin{abstract}
Abstrak: Prinsip Keselamatan Kristen mengangkat isu persamaan hak antara pria dan wanita dimana keselamatan tidak ditentukan oleh perbedaan gender. Namun dalam tatanan masyarakat Jawa yang secara tradisi dan kultur masih didominasi oleh kaum pria, filosofi "swarga nunut, neraka katut" masih berakar erat dan memengaruhi persepsi wanita Jawa, khususnya yang masih memegang teguh tradisi. Masyarakat 5.0 membawa paradigma baru bahwa di tengah arus global-digital, teknologi hadir untuk lebih memanusiakan manusia dan mengembalikan harkat dan martabat manusia secara utuh. Bagaimana perkembangan teknologi yang mengubah tatanan kehidupan ini dapat dimanfaatkan dalam mentransformasi Misi Kristen pada wanita Jawa mengambil keputusan mandiri dalam keselamatan menjadi isu utama pembahasan. Metode untuk menjawab pertanyaan penelitian memakai metode studi Biblika dan riset literatur berbasis kontekstualisasi budaya dan implementasinya secara praktis di era Masyarakat 5.0 menjadi pilihan utama. Kesimpulan yang diambil mengarah pada kebenaran perlunya mengubah paradigma berpikir bahwa keselamatan merupakan keputusan pribadi yang tidak tergantung pada perbedaan gender dan ikatan tradisi. Kebaharuan penelitian ini terletak pada eksplorasi Biblika yang secara khusus menjawab filosofi Jawa tentang "swarga nunut, neraka katut" dengan memanfaatkan karakteristik era Masyarakat 5.0.
\end{abstract}

Kata kunci: keselamatan, masyarakat 5.0, transformasi, tradisi, wanita Jawa

Abstract: The Christian Salvation Principle raises the issue of equal rights between men and women where salvation is not determined by gender differences. However, in Javanese society, which is traditionally and culturally still dominated by men, the philosophy of "swarga nunut, neraka katut" is still deeply rooted and influences the perception of Javanese women, especially those who still adhere to tradition. The era of society 5.0 brings a new paradigm that in the midst of global - digital flows, technology is present to more humanize humans and restore human dignity as a whole. How the development of technology and in life can be utilized in transforming the Christian mission for Javanese women to make independent decisions in safety is the main issue of discussion. Methods to answer research questions using Biblical study methods and literature research based on cultural contextualization and its practical implementation in the era of society 5.0 are the main choices. The conclusions drawn lead to the truth of the need to change the paradigm of thinking that salvation is a personal decision that does not depend on gender differences and traditional ties. The novelty of this research lies in the exploration of the Bible which specifically answers the Javanese philosophy of "swarga nunut, neraka katut", by utilizing the characteristics of the era of society 5.0.

Keywords: salvation, society 5.0, transformation, tradition, Javanese women 


\section{PENDAHULUAN}

Dalam satu abad terakhir, dunia telah memasuki era modern dimana segala sesuatu mengarah pada tatanan masyarakat global. Manusia terhubung secara global dalam komunitas masyarakat dunia. Segala sesuatu yang terjadi di belahan bumi manapun dapat diketahui dan diikuti perkembangannya dalam hitungan menit dan bahkan detik. Modernisasi dan digitalisasi telah mewarnai gaya hidup masyarakat abad ini, sehingga tanpa sadar perubahan yang dinamis ini akan selalu berpotensi pada perubahan tata nilai, yang pada akhirnya membawa pada perubahan gaya hidup, cara pandang dan proses pengambilan keputusan. Ide ini ditegaskan oleh Schwab ${ }^{1}$ yang menyatakan bahwa: melihat adanya perubahan nilai etis, moral, dan identitas yang kemudian berdampak pada perubahan nilai kemanusiaan.

Namun demikian, ada banyak tradisi dan nilai budaya masih dipegang teguh dan tidak mudah luntur atau terdistorsi oleh modernisasi. Salah satu tradisi dan nilai budaya yang masih mengakar kuat sampai saat ini adalah nilai adat yang dipegang oleh masyarakat Jawa, yaitu "swarga nunut, neraka katut" yang diartikan sebagai fitrah wanita Jawa (akan ke surga atau ke neraka pada kehidupan setelah kematian) ditentukan oleh kehidupan suaminya selama di dunia. Jika suami hidup baik dan dianggap oleh Tuhan layak masuk surga, maka istri akan ke surga mengikuti suaminya. Demikian juga jika suami hidup tidak baik dan dianggap layak masuk neraka oleh Tuhan, maka istri juga akan "katut" (terikut) ke neraka.

Prinsip keselamatan ini menjadi persoalan tersendiri bila dipandang dari perspektif iman Kristen dan Misiologi karena perempuan dianggap tidak memiliki hak dan kemampuan untuk menentukan nasibnya sendiri, padahal asas-asas yang terkandung dalam Missio Dei bertentangan dengan pengertian tersebut. Era

\footnotetext{
${ }^{1} \mathrm{~K}$ Schwab, "Revolusi Industri Keempat," in Lenda Dabora J.F. Sagala, Tugas Pedagogis Gembala Dalam Menyiapkan Warga Gereja Dalam Menghadapi Perubahan Sosial. Evangelikal: Jurnal Teologi Injili Dan Pembinaan Warga Jemaat Volume 4, Nomor 2, Juli 2020: 169 (Jakarta: Gramedia Pustaka Utama, n.d.).
}

Masyarakat 5.0 sesungguhnya mengemban misi luhur agar di tengah kekacauan degradasi nilainilai kemanusiaan yang mulai pupus oleh kecanggihan digitalisasi dalam modernisasi, tataran Masyarakat 5.0 justru ingin membawa manusia kembali kepada fitrahnya, yaitu manusia sebagai subjek perubahan dan pemain utama dalam perubahan zaman, bukan sebagai obyek yang pada akhirnya menjadi korban kemajuan teknologi.

Cox menyebut revolusi media massa belakangan ini laksana gelombang Tsunami yang tidak dapat dihindari dan harus dihadapi oleh setiap individu dengan cara melakukan "surfing spiritual waves." Artinya, Gereja, jika ingin memiliki pengaruh yang besar dalam memainkan peran sebagai garam dan terang, jangan melawan atau bahkan mengabaikan hal ini. Gereja harus cakap dalam memahami peran vital yang sedang dimainkan di kancah media teknologi informasi. Kegagalan memahami konteks berteologi di zaman ini akan membuat gereja berada di belakang atau menjadi an important tool in our modern global environment. ${ }^{2}$

\section{METODE}

Jawaban atas masalah penelitian didapatkan melalui pendekatan fenomenologis secara deskriptif kuantitatif, yaitu menarik secara ringkas berbagai kondisi, situasi dan fenomena realitas sosial yang ada di masyarakat dalam penelitian untuk mendapatkan suatu gambaran atas fenomena teretentu. ${ }^{3}$ Tidak hanya secara sosial, tetapi secara budaya, politik, teologis dan hak azasi manusia terhadap penelitian dominasi gender di Asia, di Indonesia dan pada wanita Jawa yang sudah dilakukan dalam 10 tahun terakhir menjadi studi utama penelitian ini. Melalui pendekatan kontekstualisasi peneliti berusaha mendapatkan sudut pandang yang tepat untuk menjawab masalah penelitian: bagaimana kajian teologis, sosial, budaya, politik

${ }^{2}$ Brandon Cox, Rewired: How Using Today's Technology Can Bring You Back to Deeper Relationships, Real Conversations, and the Age-Old Methods of Sharing God's Love (Florida: Passio Charisma House Book Group, 2014).

${ }^{3}$ Burhan Mungin, Penelitian Kualitatif (Jakarta: Kencana Media, 2007). 
dan pendekatan akan hak azasi manusia dari sudut kontekstualisasi dapat dipakai dalam mentransformasi Misi Kristen pada wanita Jawa? Pendekatan kontekstualisasi budaya dipakai, terutama dari sudut pandang teologi revolusioner dimana isu yang diangkat dalam penelitian (denominasi gender) dipandang sebagai suatu pemahaman yang perlu dirubah total. ${ }^{4}$ Dari titik ini tim penulis mencoba merumuskan langkah-langkah yang aplikatif agar Gereja dapat mengambil langkah-langkah strategis dalam mengatasi ketimpangan ketidakadilan gender di masyarakat sekitar dengan memanfaatkan ruang kekhasan era Masyarakat 5.0.

\section{PEMBAHASAN}

Berdasarkan kajian atas riset dominasi gender sebelumnya, isu ketidakadilan gender yang diterima wanita merupakan isu global yang sering dijumpai di belahan dunia manapun. Di kawasan Asia Pasifik dan negara sekutu Melayu, issue ini masih menjadi masalah yang sulit dipulihkan karena sudah mendarah daging dalam sistem tata nilai dan budaya masingmasing konteks masyarakat.

\section{Latar Belakang Dominasi Gender di Asia, Indonesia dan Masyarakat Jawa}

Ada beberapa faktor pendukung mengapa secara gender, pria lebih dominan dari wanita. Goldberg menyatakan faktor fisiologi sebagai unsur utama. Hal ini disebabkan karena ada beberapa fakta kehadiran pria secara hirarki dalam lingkungan dan faktor jenis kelamin memotivasi pria lebih kuat, membuat pria memiliki kebutuhan lebih kuat dan lebih siap, yang diwujudkan dalam perilaku apa pun, dalam situasi tertentu, yaitu perilaku yang diperlukan untuk mencapai dominasi dalam hierarki hubungan pria-wanita. ${ }^{5} \mathrm{Hal}$ ini mengakibatkan

${ }^{4}$ David D Bosch, Transformasi Misi Kristen - Sejarah Teologi Misi Yang Mengubah Dan Berubah (Jakarta: BPK Gunung Mulia, 2012).

${ }^{5}$ Stephen Goldberg, "Response to Leacock and Livingston: Discussion and Debate," American Anthropologist 771 (1975): 70-1. hubungan gender, seperti semua hubungan sosial, bersifat multi-relasi; pria dan wanita mewujudkan ide, nilai, dan identitasnya; mereka mengalokasikan tenaga kerja melalui tugas, aktivitas, dan domain yang berbeda-beda; pria dan wanita menentukan distribusi sumber daya; dan menetapkan otoritas, agensi, dan kekuatan dalam pengambilan keputusan. ${ }^{6}$

Jadi dominasi pria dan wanita diatur secara alamiah berdasarkan keadaan fisiologis dan kultur yang mengatur peran setiap gender dalam kodrat alamiahnya. Hal ini bukan semata-mata kemauan pria untuk lebih dominan saja, tetapi sejak awal memang alam men-design-nya demikian.

Melalui penelitiannya tentang Perempuan dan Gender di Asia Tenggara, Barbara Andara memberikan titik fokus lain disamping aspek dominasi pria terhadap wanita, yaitu bahwa di sisi lain, ada angin segar untuk persamaan hak antara laki-laki dan perempuan yang mulai masuk ke Indonesia ketika VOC mulai beroperasi di Batavia. Keterlibatan aktif perempuan dalam perekonomian dapat dilihat dari perannya dalam serikat pekerja. Bahwa perempuan dapat berpartisipasi dalam kancah organisasi, ekonomi dan sosial menjadi fenomena baru dalam tatanan sosial laki-laki dan perempuan di Indonesia saat itu. ${ }^{7}$ Keadaan ini menegaskan bahwa walaupun secara kodrat berbeda, namun pria dan wanita dapat membentuk suatu kehidupan yang harmoni, dimana wanita dalam sisi tertentu mampu menunjukkan kemampuan yang sama dengan pria dalam hal membangun kehidupan ekonomi, baik dalam skala kecil maupun yang lebih besar.

Menguatkan studi yang telah dilakukan oleh Andara, Scroter menemukan bahwa, dipengaruhi oleh tradisi Islam yang masuk ke Indonesia sekitar abad ke-7, masyarakat Aceh menerima perempuan sebagai pemimpin dalam

${ }^{6}$ Reversed Kabeer, N, Realities: Gender Hierarchies in Development Thought. (London and New York: Verso in Social and Gender Analysis in Natural Resources Management; Learning Studies and Lessons From Asia., ed. Ronny Vernooy (Chine Agriculture Press: sage publications, 2006).

${ }^{7}$ Barbara Andaya, "International Journal of Asian Studies", 41 (2007): 113-136 Cambridge University Press Printed in the United Kingdom." (2007): 122. 
dunia politik dan sosial dimana otoritas mereka dihormati oleh masyarakat yang terlihat dari kepemimpinan Sultanah Tajul Alam Safiatuddinsyah (1641-1675), Sultanah Nur Alam Naqiatuddin Syah (1675-1678), Sultanah Inayat Zakiatuddin Syah (1678-1688), Sultanah Kamalat Zainatuddin Syah (1688-1699). Begitu juga perempuan sebagai panglima perang melawan penjajahan Belanda, yaitu Cut Mutia dan Cut Nyak Dien.

Hal ini tidak hanya terjadi di Aceh, tetapi kepemimpinan perempuan melawan imperialisme barat menyebar ke seluruh nusantara di Indonesia pada waktu itu. ${ }^{8}$ Fakta ini membawa pada pemikiran baru bahwa sekalipun secara tradisi wanita hidup dalam dominasi pria, namun pria dapat menerima kepemimpinan dan otoritas wanita dalam bidang politik dan pemerintahan. Ketundukan dalam hal yang khusus, yaitu ketundukan kepada pemimpin wanita tidak serta merta disangkutpautkan dengan ketundukan absolut.

Penelitian Peletz tentang wanita modern di Asia Pasifik menemukan bahwa wanita Indonesia di sekitar tahun 1960-an ada dalam upaya untuk diorganisir kekuatannya melalui sebuah forum yang disebut GERWANI (Gerakan Wanita Indonesia). Meski dalam proses selanjutnya organisasi ini disinyalir dieksploitasi oleh kepentingan politik tertentu dan berkonotasi negatif, namun dari organisasi ini, pada akhirnya, di masa depan dibentuk wadah pemberdayaan potensi perempuan Indonesia, yaitu PKK (Pendidikan Keluarga Kesejahteraan) dan Dasa Wisma. Sekali lagi, kesejahteraan keluarga menjadi prioritas utama, yang semakin memperkuat peran perempuan dalam kesejahteraan keluarga. ${ }^{9}$

Melalui beberapa studi tentang gender di atas, secara institusional di masyarakat, perempuan dapat mengambil peran penting dalam dunia politik, ekonomi dan kesejahteraan keluarga, namun kemajuan tersebut belum

\footnotetext{
${ }^{8}$ Susanne Schroter, Woman's Rights Movement Religious Resurgence and Local Tradition (Leiden: Boston, 2013).

${ }^{9}$ Michael G Peletz, "Gender, Sexuality, and the State in Southeast Asia,71, 4 (2012): 895-917," The Journal of Asian Studies 71, No 4 (2012): 895-917.
}

mampu menghapus fakta bahwa kodrat perempuan masih dianggap sebagai warga negara kelas dua, yang dianggap tidak bisa mengambil keputusan sendiri, hidup masih di bawah bayang-bayang pria (suami).

Brenner memberikan data-data penting melalui sebuah studi tentang demokrasi - Islam gender di Indonesia, yaitu bahwa dominasi pria atas wanita sedikit banyak dipengaruhi oleh tradisi Islam yang masuk ke Indonesia. Melalui wawancara inklusif dengan Rifka Annisa (mahasiswi yang sedang belajar hukum keluarga Islam di sebuah universitas Islam dan menjadi sukarelawan di lembaga tersebut), terungkap bahwa "semangat dasar Islam adalah semangat keadilan." "Keadilan sosial total" adalah cermin dari semangat Islam yang "ideal." Tidak sama dengan Islam "budaya" yang terdistorsi dari waktu ke waktu. Semangat Islam ideal sama dengan semangat feminisme yang berkembang di Barat. Rifka Anisa menggumuli pertanyaan: mengapa wanita diperlakukan hanya sebagai "setengah manusia?" 10

Bila demikian kecenderungannya, yaitu bahwa wanita dianggap sebagai bukan manusia seutuhnya sehingga hanya dipandang sebagai manusia kelas dua, asas di atas relevan dengan budaya bangsawan Jawa pada masa lalu yaitu dominasi laki-laki atas perempuan digambarkan dengan dimungkinkannya seorang raja beristri lebih dari satu, bahkan sampai lima puluh istri asalkan yang bersangkutan mampu memberikan nafkah kepada isteri-isterinya secara adil. Fakta ini mengarah pada pemahaman bahwa dominasi raja (yang berkuasa) diturunkan menjadi model ideal dominasi laki-laki saat itu. Jadi tidak heran bila dalam konteks budaya saat itu, wanita dianggap sebagai objek kehidupan pria, tidak dapat memberikan kontribusi selain kepuasan seksual dan melahirkan anak bagi suaminya.

Sukamto membenarkan pandangan di atas dengan menyatakan bahwa sebenarnya agama Kristen maupun Islam lahir dalam konteks budaya yang sangat patriakhal dimana garis utama dalam masyarakat adalah kaum laki-laki.

${ }^{10}$ Suzanne Brenner, "Private Moralities in the Public Sphere: Democratization, Islam, and Gender in Indonesia, AMERICAN ANTHROPOLOGIST," the American Anthropological Association. All rights reserved 113, 3 (n.d.). 
Karena menganut sistem patriakhal dimana para penafsir teks didominasi oleh laki-laki, maka hasil penafsiran ayat-ayat dalam teks suci bayak memihak kaum laki-laki ketimbang perempuan. Hasil tafsir tersebut kemudian menjadi bias sehingga menjadi salah satu penyumbang munculnya gender inequalities dimana bentuk ketidakadilan gender diekspresikan melalui diskriminasi dan kekerasan yang dialami kaum wanita. ${ }^{11}$

Jadi, benar bila Trebilcock menulis bahwa secara universal, keterlibatan dan keterwakilan perempuan dalam serikat pekerja masih rendah, terutama di tingkat kepemimpinan dan pengambilan keputusan. ${ }^{12}$ Temuan ini ditegaskan kembali oleh Kirton yang menambahkan bahwa fenomena ini juga terlihat jelas di banyak negara Asia Selatan. ${ }^{13}$ Masih di Asia, Glenda mengemukakan bahwa partisipasi yang rendah dari kaum wanita terlihat juga di tingkat pembuatan kebijakan di pemerintahan dan organisasi yang menimbulkan pertanyaan tentang bagaimana partisipasi perempuan yang adil dalam proses dialog sosial. ${ }^{14}$ Jadi pendek kata, partisipasi wanita di Asia Selatan tercatat masih memiliki tingkat partisipasi angkatan kerja yang rendah. ${ }^{15}$

Dengan demikian, dapat dilihat bahwa dominasi gender pria atas wanita bukan hanya terjadi dalam konteks masyarakat Jawa, tetapi juga di Indonesia, di negara-negara Asia dan negara lain pada umumnya. Hal ini didorong oleh faktor fisiologis, agama, tradisi dan budaya,

${ }^{11}$ Sukamto, "Status Perempuan Dalam Tafsir Teks Suci: Studi Singkat Pada Dua Agama Besar Islam Dan Kristen,” Jurnal Transformasi, STT-INTI Bandung 7, 1 (2011).

${ }^{12}$ A. Trebilcock, "A, Strategies for Strengthening Women's Participation in Trade Union Leadership," International Labor Review 130,4 (1991).

${ }^{13}$ G. Kirton and G. Healy, "Shaping Union and Gender Identities: A Case Study of Women-Only Trade Union Courses.," British Journal of Industrial Relations 42, 2 (2004): 303-323.

${ }^{14}$ Glenda Strachan, Arosha Adikaram, and Payithra Kailasapathy, "Gender (In)Equality in South Asia: Problems, Prospects and Pathways, SAGE Publications India Private Limited SAGE Publications.," South Asian Journal of Human Resources Management 2, 1 (2015): 1-11.

${ }^{15}$ Ibid. yang tercermin dalam kehidupan sosial, ekonomi dan politik.

Kebaharuan penelitian ini ada dalam pengkombinasian kupasan teologis, budaya, tata nilai baru era society 5.0, sosial, politik dan hak asasi manusia dalam mendapatkan pendekatan tentang bagaimana bermisi secara kontekstual di zaman ini. Hasil penelitian ini diharapkan memberikan kontribusi bagi Gereja dalam membangun jembatan misi dan mentransformasi pemikiran Mastarakat Jawa dalam konsep keselamatan berdasarkan issue gender di era Masyarakat 5.0. Gereja mampu membangun paradigm baru dalam bermisi secara lebih kontekstual, sehingga pesan Injil dapat mendarat lebih mulus dan smooth ke dalam konteks masyarakat Jawa dan komunitas lain secara umum.

\section{Persepsi yang Salah dan Pengertian yang Benar Tentang Keselamatan di Kalangan Wanita Jawa}

Berdasarkan data dan hasil penelitian yang telah dipaparkan, perlu adanya pemulihan perspektif dan keadilan bagi perempuan Jawa dalam hal memiliki kesetaraan hak dalam menentukan pilihan akan jalan keselamatan kekal. Beberapa kajian di bawah ini merupakan faktor pendukung yang selama ini sudah menjadi dasar persepsi yang kurang tepat yang perlu diluruskan. Kebutuhan itu didasarkan pada hal-hal berikut:

\section{Perspektif Teologis}

Setelah kejatuhan manusia dalam dosa, kebutuhan manusia yang paling utama adalah dipulihkannya kembali status dan hubungan dengan Allah sehingga Tuhan memiliki misi agar seluruh manusia diselamatkan (1 Timotius 2:4). "Misi Allah" dalam frasa Bahasa Latin diartikan sebagai Missio Dei, yang merujuk pada aksi gereja (baik secara personal maupun kelembagaan) terlibat dalam pekerjaan (misi) Allah, yaitu penyelamatan umat manusia, sebagaimana yang ditulis oleh Henry W Spaulding II dan Henry W Spaulding III, 
Missio Dei common translated as The Mission of God. In the modern church, one sees how the mission can function as an ideal or concept or strategy. How the mission of God possesses content as action, or a habbits ... This denotes the fact that the mission of God for the church is an action taken upon every individual as well as the church universal or habitus constructs as the way the church acts publically. ${ }^{16}$

Mencermati studi eksegesis yang dilakukan Yongky Karman dalam eksistensi perempuan dalam gambar Allah, ditemukan bahwa kesetaraan antara laki-laki dan perempuan jangan dipahami secara dangkal sebagai kesamaan dalam segala peran dan aktivitas. Lakilaki dan perempuan dijadikan dengan konstruksi tubuh dan kapasitas yang berbeda. ${ }^{17}$ Dalam pandangan yang lebih modern, Karl Barth mengemukakan gagasan bahwa Misi adalah pekerjaan Tuhan dan bahwa Misi Gereja yang otentik harus sesuai dengan misi Tuhan. Ide ini diambil oleh Hartenstein yang menggunakan istilah Missio Dei untuk membedakannya dari missio ecclesiae atau misi gereja. ${ }^{18} \mathrm{Jadi}$, Missio Dei bukan hanya sekedar prinsip atau konsep akademis dan cukup dapat dipahami pada tataran kognitif, tetapi Missio Dei perlu diterjemahkan ke dalam hal-hal yang praktis agar prinsip tersebut dapat menjadi nyata, dapat dilihat, dapat dirasakan dan dapat membawa perubahan pada dunia. Prinsip gereja melalui Missio Dei erat kaitannya dengan prinsip peran gereja dalam konteks gerejawi. Jadi Gereja (orang atau lembaga) dipanggil untuk menjangkau orang-orang bagi Tuhan. Gereja dipanggil untuk memasuki berbagai komunitas sekitar dan membawa pesan keselamatan kepada orangorang dengan berbagai cara.

Prinsip dalam 1 Timotius 2:4 relevan dengan makna keselamatan yang terkandung dalam Galatia 3:26-29, yaitu: "sebab kamu semua adalah anak-anak Allah karena iman di dalam Kristus Yesus. Karena kamu semua, yang dibaptis

\footnotetext{
${ }^{16}$ Henry W Spaulding II and Henry W Spaulding III, Trinitarian Identity: The Church's True Foundation, n.d.

${ }^{17}$ Yongky Karman, "Perempuan Sesama Penyandang Allah,” in Bunga Rampai Perjanjian Lama (2007)., n.d.

${ }^{18}$ Bevans. S. B. and R. P. Schoeder, Constants In Confict: A Theology Of Mission For Today (Maryknoll: NY. Orbis Books, 2004).
}

dalam Kristus, telah mengenakan Kristus. Dalam hal ini tidak ada orang Yahudi atau orang Yunani, tidak ada hamba atau orang merdeka, tidak ada laki-laki atau perempuan, karena kamu semua adalah satu di dalam Kristus Yesus. Dan jikalau kamu adalah milik Kristus, maka kamu juga adalah keturunan Abraham dan berhak menerima janji Allah."

Dari 1 Timotius 2:4, "seluruh manusia" mengacu pada pengertian bahwa Allah menyediakan keselamatan bagi semua orang, pria dan wanita. "Semua manusia" merujuk pada tidak adanya perbedaan antara laki-laki dan perempuan di mata Allah, yang berarti bahwa semua orang, laki-laki dan perempuan, memiliki kedudukan yang sama di hadapan Tuhan dalam hal memperoleh keselamatan (kehidupan kekal). Ungkapan "laki-laki dan perempuan" dalam Galatia 3:26-29 menyiratkan bahwa keselamatan disediakan terlepas dari jenis kelaminnya. Lakilaki dan perempuan, sama-sama mendapatkan kesempatan dan hak di hadapan Tuhan. Keputusan untuk memercayai Yesus Kristus sebagai Juru Selamat dapat dilakukan oleh seseorang (wanita juga), dimana keduanya memiliki kualitas keselamatan yang sama.

Masih menurut Yongky, subordinasi istri tidak merendahkan martabatnya. Penguasaan suami hanya atas gairah istri, bukan seluruh hidupnya, sebagaimana kata mašal juga dipakai untuk tindakan mengontrol tanpa menindas ketika Allah memerintah atas bangsa-bangsa (Mzm. 22:29). ${ }^{19}$ Jadi, secara teologis, Allah sebagai inisiator keselamatan manusia, tidak ada memberikan perbedaan antara pria dan wanita dalam hal memperoleh keselamatan. Perbedaan hak atas keselamatan seperti yang dipahami orang Jawa tentang "swarga nunut, neraka katut" bertentangan dengan prinsip Tuhan tentang keselamatan secara teologis. Allah tidak membedakan gender dalam hal memperoleh keselamatan. Mencermati temuan-temuan penelitian dominasi gender di atas, berarti persamaan gender terhadap wanita sudah mendapat porsi atau diakui hak-haknya oleh Tuhan, sehingga jika konsep swarga nunut neraka Allah."
${ }^{19}$ Yongky Karman, "Perempuan Sesama Penyandang 
katut masih dipegang teguh oleh wanita Jawa, berarti bisa jadi karena itu pilihan kaum wanita sendiri dan bukan karena tidak diakomodir haknya sebagai wanita oleh pihak lain (kaum pria).

\section{Perspektif Hak Azasi Manusia}

Hak asasi manusia dilindungi oleh undangundang. Perserikatan Bangsa-Bangsa (PBB) juga memastikan bahwa setiap warga dunia mendapatkan hak asasinya sebagai manusia. United Nation for Gender Equality and the Empowerment of Woman merupakan salah satu komisi di bawah kordinasi PBB yang memperjuangkan keadilan bagi perempuan, khususnya perempuan di seluruh dunia. Hal ini secara yuridis merupakan pengakuan masyarakat dunia bahwa hak perempuan perlu disamakan dengan laki-laki dalam hal hak asasinya. ${ }^{20}$ Paragrap pertama Pembukaan Undang-undang Dasar (UUD) 1945 mendukung perjuangan hak asasi manusia tersebut, demikian:

"bahwa sesungguhnya kemerdekaan itu ialah hak
segala bangsa dan oleh sebab itu, maka penjajahan
di atas dunia ini harus dihapuskan karena tidak
sesuai dengan perikemanusiaan dan perikeadilan."

Bagian ini sesuai dengan batang tubuh UUD 1945 pasal 27 tentang warga negara ayat 2, dimana tiap-tiap warga negara berhak atas pekerjaan dan penghidupan yang layak bagi kemanusiaan. ${ }^{22}$ Ditambah lagi, sesuai dengan hak warga negara dalam bidang Agama di Pasal 29 ayat 2, negara menjamin kemerdekaan (diterjemahkan: kebebasan untuk memilih) tiaptiap penduduk untuk memeluk agamanya masing-masing dan untuk beribadah menurut agama dan kepercayaannya itu. ${ }^{23}$ Maka wanita, terlepas dari asal suku dan tradisi yang dijaganya, memiliki hak untuk menentukan jalan keselamatan kekal. Keselamatan kekal yang tidak

\footnotetext{
20"Pbb-Luncurkan-Organisasi-Bela-Hak-Wanita."

${ }^{21}$ Naskah Pembukaan Undang Undang Dasar Indonesia (Jakarta, 1945).

${ }^{22}$ Naskah Pembukaan Undang Undang Dasar Indonesia, Pasal 27 (Jakarta, 1945).

${ }^{23}$ Naskah Undang-Undang Dasar Indonesia Pasal 29 (Jakarta, 1945).
}

tergantung pada pria, suami atau pihak-pihak lainnya.

\section{Perspektif Budaya}

GKR Alit mengungkapan bahwa pemahaman "swarga nunut neraka katut" yang dihubungkan dengan kaum perempuan timbul karena perempuan sebagai isteri hanya disuruh mengikuti aturan di rumah tangga sedangkan yang menjadi kepala rumah tangga adalah bapak. Kalau rumah tangga baik, isteri juga akan baik, tetapi bila rumah tangga jelek maka isteri juga menjadi jelek dan katut ke neraka. Isteri hanya sebagai "kanca wingking" yang bekerja di dapur untuk menyiapkan keperluan rumah sedangkan bapak (suami) sebagai kepala keluarga adalah pihak yang menjamu tamu. ${ }^{24}$

Lebih lanjut dipaparkan bahwa idealisme tentang kesejajaran wanita dengan pria yang tumbuh dalam masyarakat jawa, mengalami kesurutan (luntur) dengan timbulnya budaya feodalisme aristokrasi dalam masyarakat Jawa. Pandangan untuk memposisikan kedudukan pria dalam melestarikan keturunan diformalkan dalam kehidupan sosial maupun budaya (adat istiadat) yang melemahkan posisi kaum wanita. ${ }^{25}$ Ideologi familialisme menghasilkan produk sistem patrimonial baik dalam kehidupan rumah tangga maupun dalam masyarakat, peran pria (laki-laki) sangat nampak sebagai penguasa dan penentu keluarga atau masyarakat. Pria dalam sistem patrimonial lebih cenderung mendapat hak-hak istimewa, akibatnya sistem ini mengarah pada budaya otoriter bagi kaum pria dan wanita dipandang sebagai subordinasi. Sistem patrimonial sangat melumpuhkan peran dan kedudukan wanita, wanita terpola menjadi pasif karena dibelenggu oleh budaya diarahkan dan diperintah. ${ }^{26}$

Globalisasi, sedikit banyak, perlahan namun pasti, disetujui atau tidak, akan membawa perubahan pada tatanan masyarakat global sehingga nilai-nilai universal akan lebih diterima

${ }^{24}$ Jozef M.N. Hehanussa, "Perempuan Dalam Budaya Jawa.," in Pieternella van Doorn-Harder Dengan GKR Alit (kaliurang: pada museum batik, 1998).

${ }^{25}$ Ibid.

${ }^{26} \mathrm{Ibid}$. 
oleh masyarakat dunia, terutama yang mendukung hak asasi manusia, keadilan, kebenaran dan humanistik. Jadi, jelas di sini bahwa prinsip "swarga nunut, neraka katut" tidak dapat dipertahankan lagi karena berbenturan dengan nilai-nilai kemanusiaan.

\section{Perspektif Sosial Politik}

Secara sosial, mengebiri hak perempuan untuk menentukan pilihan agama dan jalan keselamatan tidak relevan dengan kondisi saat ini. Era globalisasi membawa manusia hidup dalam standar dan tatanan baru. Ada standar etika dan budaya yang berlaku secara universal dan global. Ketimpangan dalam mendapatkan keadilan bagi perempuan akan menjadi preseden buruk bagi pemerintahan suatu negara, yang berakibat pada menurunnya popularitas dan reputasi suatu negara atau masyarakat.

Masyarakat dunia cenderung memberikan dukungan terhadap nilai-nilai keadilan gender, bahkan di beberapa belahan dunia gerakan feminisme mendapat simpati dan perhatian dari masyarakat dunia. Hal ini berkaitan langsung dengan politik suatu negara.

\section{Pemulihan Keadilan bagi Wanita Jawa}

Perempuan Jawa perlu mengalami restorasi hak, menentukan jalan keselamatan bagi dirinya sendiri. Hak-hak perempuan perlu dipulihkan agar sesuai dengan tujuan Tuhan dan sesuai dengan norma-norma yang berlaku dalam masyarakat, dan sejalan dengan prinsip Missio Dei. Restorasi keadilan bagi perempuan Jawa dibangun pada pemahaman bahwa perempuan Jawa bukanlah masyarakat kelas dua yang hanya tunduk kepada laki-laki (suami), tetapi sebagai pribadi yang utuh, menurut gambar dan rupa Allah, perlu menentukan pilihan pribadi atas keselamatan abadinya. Mengubah paradigma berpikir merupakan bagian penting dari proses transformasi masyarakat, yang dalam konteks penelitian ini adalah masyarakat Jawa.

\section{Peran Gereja dalam Mengembalikan Harkat dan Hak Wanita dalam Memilih Jalan Keselamatan di Era Masyarakat 5.0}

Gereja memainkan peran yang sangat strategis dalam mentransformasi masyarakat melalui penegakan keadilan, misalnya dengan memberikan pemahaman mengenai gambar diri atau mengapa wanita itu bernilai, sehingga bisa mengambil keputusan. Hal ini didasarkan pada pemahaman bahwa Gereja mengemban misi Allah untuk keselamatan manusia. Kesejahteraan dan keadilan perlu diperjuangkan di dunia untuk memperkuat peran gereja sebagai saksi Kristus. Sejalan dengan itu, dalam dunia digital di era Masyarakat 5.0, Gereja dituntut untuk mengeluarkan kemampuan beradaptasi dan terus berpikir bagaimana mengisi kehidupan baru yang perlu penyesuaikan ini dengan memanfaatkan teknologi yang ditawarkan sebagai sarana mewartakan, merayakan dan memberikan kesaksian iman kepada dan untuk umat. Fransiskus Irwan Widjaja menuliskan bahwa perubahan tatanan ini lebih banyak bersumber pada perubahan kognitif, yang didahului oleh kasih sayang yang membentuk keterampilan bersikap sosial dalam budaya manusia. Oleh karena itu, pergeseran paradigma kognitif secara bersamaan melahirkan perubahan signifikan dalam domain lain, yang membentuk budaya baru yang disebut era postmodern. ${ }^{27}$

Berdasarkan pemahaman ini, penyesuaian yang diperlukan Gereja adalah berusaha menjawab: pendekatan dan metode mana yang paling tepat untuk dipakai Gereja terkait prinsip Missio Dei di era Masyarakat 5.0? Gereja perlu melek digital dalam menjalankan misinya. Hal ini semata-mata agar tujuan Gereja sebagai perpanjangan tangan misi Allah dapat dikerjakan secara kontekstual dan adaptif, tanpa kehilangan esensinya.

Penelitian Octavianus menunjukkan telah terjadi perubahan pola komunikasi Injil dimana

\footnotetext{
${ }^{27}$ Fransiskus Irwan Widjaja, Fredy Simanjuntak, and Noh Ibrahim Boiliu, "Repositioning Mission in Postmodern Culture," in Proceedings of the 1st International Conference on Education, Society, Economy, Humanity and Environment (ICESHE 2019) (Paris, France: Atlantis Press, 2020).
} 
peluang yang disediakan di era revolusi industri 4.0 memberi kesempatan kemudahan komunikasi Injil, tetapi hal ini hanya dapat berhasil jika ada peran serta gembala dalam melakukan pembinaan warga gereja untuk memanfaatkan situasi ini. ${ }^{28}$ Temuan ini memberikan petunjuk bahwa sumber daya manusia tidak menjadi satu-satunya resources dalam penjangkauan jiwa, tetapi juga alat, metode, koneksi berjejaring dalam tataran dunia maya turut menentukan keberhasilan itu.

Stedzer menawarkan tiga hal terkait bagaimana gereja dapat memanfaatkan teknologi digital ini dalam memenuhi panggilan ekklesiologis-misionalnya, antara lain, yaitu Technology Enables Communication, Technology Enables Community dan Technology Enables Discipleship. ${ }^{29}$ Technology Enables Communication adalah aspek teknologi yang dapat dipakai Gereja dalam mengembangkan komunikasi dengan jemaat. Media sosial menjadi pilihan utama melalui komunitas maya berbasis jaringan internet lainnya. Secara praktis, Gereja dapat mengembangkan model pendekatan ini dalam membangun komunikasi Injil dengan jemaat dan komunitas tertentu.

Technology Enables Community dapat dipakai Gereja untuk mengokohkan paradigma bahwa terhubung tidak selalu berarti berkumpul. Fleksibilitas ruang dan waktu yang tinggi sangat memungkinkan pertemuan dan pengembangan komunitas dilakukan dimana saja dan kapan saja. Banyak Gereja di masa pandemi Covid 19 dapat survive dan bahkan berkembang pelayanannya di bidang-bidang tertentu karena mampu beradaptasi dengan memanfaatkan media online, misalnya pelayanan bagi segmen ibu-ibu muda melalui aplikasi Instagram Live.

Sedangkan Technology Enables Discipleship adalah bagaimana Gereja dapat memakai platform media untuk melayani jemaat dalam hal pengajaran Alkitab atau penguatan dasar-dasar Iman Kristen. Sharing materi khotbah atau bahan

${ }^{28}$ J.F Sagala Lenda Debora, "Peran Pedogogis Gembala Dalam Menyiapkan Warga Gereja Menghadapi Perubahan Sosial," Evangelikal: Jurnal Teologi Injili dan Pembinaan Warga Jemaat 4, 2 (2020).

${ }^{29}$ Ed Stedzer, "Ways-Technology-Enables-Mission-ofChurch." diskusi kelompok sel dapat dengan mudah didistribusikan kepada jemaat atau komunitas. Kemudahan akses materi pengajaran menjadi salah satu bentuk pelayanan penting untuk memenuhi kebutuhan jemaat akan pengajaran Firman Tuhan yang benar. Banyak Gereja menyajikan khotbah dan sesi-sesi pembinaan iman melalui plafform youtube yang dapat diakses kapan saja. Pelayanan kaum wanita dalam hal memberikan pengajaran dan membentuk dasardasar iman juga perlu inovatif dan kreatif. Pembinaan iman dalam kelompok sel dapat dilakukan secara terkordinir memanfaatkan media yang ada.

Pada era saat ini, dengan perkembangan zaman proses pemberian bantuan atau konseling tidak hanya dapat dilakukan sacara tatap muka (face to face), melainkan berkembang dengan dapat dilakukannya proses konseling secara online atau dapat disebut cybercounseling, ecounseling, konseling online. Menurut Li, Lau, Jaladin, dan Abdullah dalam pelaksanaannya ada beberapa istilah yang biasa digunakan untuk dalam penyebutan konseling online termasuk terapi online atau internet, konseling elektronik, terapi elektronik, terapi cyber, terapi menggunakan email, konseling berbasis web, konseling internet, konseling cyber, konseling sesi tunggal sinkron, dan terapi-e-mail. ${ }^{30}$

Dalam konteks membangun jembatan misi kepada komunitas, memberikan pengajaran kepada jemaat yang tentang konsep keselamatan, dan membentuk pemahaman yang benar kepada kaum wanita dan pria tentang nilai budaya yang yang perlu dipertahankan, disesuaikan atau direduksi, Gereja perlu memanfaatkan berbagai platform media yang ada yang dipakai oleh masyarakat zaman sekarang. Gereja yang jemaat dan komunitas di sekelilingnya masih memiliki pemahaman yang keliru mengenai konsep keselamatan berbasis dominasi gender perlu

${ }^{30}$ Nur Mega Aris Saputra, Hengky Tri Hidayatulah, and Muslihati Zulkifli Abdulah, "Pelaksanaan Layanan Cyber - Counseling Pada Era Society 5.0," in Kajian Konseptual, Prosiding Seminar Nasional Bimbingan Dan Konseling Universitas Negeri Malang "Arah Kurikulum Program Studi Bimbingan Dan Konseling Indonesia Di Era Merdeka Belajar", 75., n.d. 
mengembangkan strategi penjangkauan yang spesifik dan terintegrasi baik.

\section{KESIMPULAN}

Menjawab pertanyaan riset: bagaimana pendekatan yang benar secara teologis, sosial, budaya, politik dan hak azasi manusia dalam tatanan kehidpan di era Masyarakat 5.0 dapat dimanfaatkan dalam mentransformasi Misi Kristen pada wanita Jawa mengambil keputusan mandiri dalam keselamatan? Berikut ini adalah hasil kajian riset untuk menjawab masalah tersebut, yaitu:

Pertama, Secara teologis, keselamatan kekal adalah hak semua pria dan wanita. Tidak ada perbedaan gender dalam mendapatkan jaminan keamanan. Latar belakang budaya apa pun tidak boleh menghalangi seseorang (wanita) untuk membuat keputusan secara mandiri demi keselamatan kekalnya.

Kedua, Gereja mengambil peran yang sangat strategis dalam mentransformasi masyarakat, khususnya masyarakat yang belum mengenal Yesus Kristus. Gereja perpanjangan tangan Tuhan perlu membangun jembatan misi agar kebenaran Injil dan pesan keselamatan didengar dan dipahami oleh seluruh umat manusia.

Ketiga, poin pertama dan kedua dari kesimpulan dapat diimplementasikan Gereja di era Masyarakat 5.0 melalui kemampuan Gereja beradaptasi dengan perubahan dan mengambil peran startegis penjangkauan jiwa dan pengajaran dasar iman Kristen melalui platform media digital. Gereja perlu beradaptasi, merubah paradigma dan menyusun pendekatanpendekatan baru tanpa kehilangan esensi Misinya dan identitasnya di tengah masyarakat plural dan global.

\section{KEPUSTAKAAN}

Andaya, Barbara. "“International Journal of Asian Studies"." 41 (2007): 113-136.

B., Bevans. S., and R. P. Schoeder. Constants In Confict: A Theology Of Mission For Today. Maryknoll: NY. Orbis Books, 2004.

Bosch, David D. Transformasi Misi Kristen -
Sejarah Teologi Misi Yang Mengubah Dan Berubah. Jakarta: BPK Gunung Mulia, 2012.

Brenner, Suzanne. "Private Moralities in the Public Sphere: Democratization, Islam, and Gender in Indonesia, AMERICAN ANTHROPOLOGIST." the American Anthropological Association. All rights reserved 113, 3 (n.d.).

Cox, Brandon. Rewired: How Using Today's Technology Can Bring You Back to Deeper Relationships, Real Conversations, and the AgeOld Methods of Sharing God's Love. Florida: Passio Charisma House Book Group, 2014.

Goldberg, Stephen. "Response to Leacock and Livingston: Discussion and Debate." American Anthropologist 771 (1975): 70-1.

Hehanussa, Jozef M.N. "Perempuan Dalam Budaya Jawa." In Pieternella van DoornHarder Dengan GKR Alit. kaliurang: pada museum batik, 1998.

II, Henry W Spaulding, and Henry W Spaulding III. Trinitarian Identity: The Church's True Foundation, n.d.

Kabeer, N, Reversed. Realities: Gender Hierarchies in Development Thought. (London and New York: Verso in Social and Gender Analysis in Natural Resources Management; Learning Studies and Lessons From Asia. Edited by Ronny Vernooy. Chine Agriculture Press: sage publications, 2006.

Kirton, G., and G. Healy. "Shaping Union and Gender Identities: A Case Study of Women-Only Trade Union Courses." British Journal of Industrial Relations 42, 2 (2004): 303-323.

Lenda Debora, J.F Sagala. "Peran Pedogogis Gembala Dalam Menyiapkan Warga Gereja Menghadapi Perubahan Sosial.” Evangelikal: Jurnal Teologi Injili dan Pembinaan Warga Jemaat 4, 2 (2020).

Mungin, Burhan. Penelitian Kualitatif. Jakarta: Kencana Media, 2007.

Peletz, Michael G. "Gender, Sexuality, and the State in Southeast Asia,71, 4 (2012): 895917." The Journal of Asian Studies 71, No 4 (2012): 895-917. 
Saputra, Nur Mega Aris, Hengky Tri Hidayatulah, and Muslihati Zulkifli Abdulah. "Pelaksanaan Layanan Cyber Counseling Pada Era Society 5.0.” In Kajian Konseptual, Prosiding Seminar Nasional Bimbingan Dan Konseling Universitas Negeri Malang "Arah Kurikulum Program Studi Bimbingan Dan Konseling Indonesia Di Era Merdeka Belajar", 75., n.d.

Schroter, Susanne. Woman's Rights Movement Religious Resurgence and Local Tradition. Leiden: Boston, 2013.

Schwab, K. "Revolusi Industri Keempat." In Lenda Dabora J.F. Sagala, Tugas Pedagogis Gembala Dalam Menyiapkan Warga Gereja Dalam Menghadapi Perubahan Sosial. Evangelikal: Jurnal Teologi Injili Dan Pembinaan Warga Jemaat Volume 4, Nomor 2, Juli 2020: 169. Jakarta: Gramedia Pustaka Utama, n.d.

Stedzer, Ed. "Ways-Technology-Enables-Missionof-Church."

Strachan, Glenda, Arosha Adikaram, and Payithra Kailasapathy. "Gender (In)Equality in South Asia: Problems, Prospects and Pathways, SAGE Publications India Private Limited SAGE Publications." South Asian Journal of Human Resources Management 2, 1 (2015): 1-11.

Sukamto. "Status Perempuan Dalam Tafsir Teks Suci: Studi Singkat Pada Dua Agama Besar Islam Dan Kristen." Jurnal Transformasi, STT-INTI Bandung 7, 1 (2011).

Trebilcock, A. "A, Strategies for Strengthening Women's Participation in Trade Union Leadership." International Labor Review 130,4 (1991).

Widjaja, Fransiskus Irwan, Fredy Simanjuntak, and Noh Ibrahim Boiliu. "Repositioning Mission in Postmodern Culture." In Proceedings of the 1st International Conference on Education, Society, Economy, Humanity and Environment (ICESHE 2019). Paris, France: Atlantis Press, 2020.

Yongky Karman. "Perempuan Sesama Penyandang Allah.” In Bunga Rampai Perjanjian Lama (2007)., n.d.

Naskah Pembukaan Undang Undang Dasar
Indonesia, Pasal 27. Jakarta, 1945.

Naskah Pembukaan Undang Undang Dasar Indonesia. Jakarta, 1945.

Naskah Undang-Undang Dasar Indonesia Pasal 29. Jakarta, 1945.

"Pbb-Luncurkan-Organisasi-Bela-Hak-Wanita." 